\title{
DOBÓR GATUNKOWY I UPRAWA ROŚLIN WE WNĘTRZACH POLSKICH PAŁACÓW I DWORÓW W XIX W
}

\author{
Halina Laskowska, Margot Dudkiewicz, Mariusz Szmagara \\ Katedra Roślin Ozdobnych i Architektury Krajobrazu, Uniwersytet Przyrodniczy w Lublinie \\ Department of Ornamental Plants and Landscape Architecture, University of Life Sciences in Lublin
}

\begin{abstract}
Streszczenie: Kwiaty były uprawiane w donicach i misach już w czasach Homera. Na ilustracjach wczesnego Egiptu widoczne są rośliny w donicach stojące w ogrodzie w symetrycznych wzorach. Na początku do wnętrz mieszkalnych dworów i pałaców przenoszono rośliny krajowe, z czasem zaczęto sprowadzać gatunki obce, przywożone przez botaników z całego świata. W artykule przedstawiono ważniejsze gatunki stosowane, jako rośliny pokojowe w XIX w., oraz opisano meble i pojemniki do ekspozycji roślin używane w tamtych czasach. W procesie aranżacji wnętrza historycznego ważne jest, aby wykonać właściwy dobór gatunkowy do stylu mieszkania.
\end{abstract}

Słowa kluczowe: pałac, dwór, rośliny doniczkowe

\section{WSTĘP}

Współcześnie w Polsce zabytkowe zespoły zieleni dworskiej stanowią dość dużą grupę określaną na 10000 obiektów. Po wieloletnich zaniedbaniach próbuje się odtworzyć pierwotne układy kompozycyjno - przestrzenne i oddać obiektom architektury rezydencjonalnej ich znaczenie, jako zabytki kultury materialnej i duchowej.

Podjęcie badań ma na celu odpowiedź jak kształtował się dobór gatunkowy roślin we wnętrzach pałaców i dworów w XIX w. na terenie Polski. Wiele z tych obiektów jest odnawianych, w wielu ponownie zamieszkują prywatne rodziny lub budynki są adaptowane na cele restauracyjne i hotelowe. Brakuje natomiast opracowań przybliżających wystrój i aranżacje zielenią dawnych mieszkań. Zakres pracy objął również dawne meble i pojemniki służące do ekspozycji roślin, historycznie używane we wnętrzach pałaców i dworów. Badania polegały na kwerendzie bibliograficznej i archiwalnej. Postępowanie studialne przeprowadzono na podstawie ikonografii - rysunków, grafik, obrazów, fotografii archiwalnych i książek napisanych przez ówczesnych ogrodników.

\section{WYNIKI}

Edmund Jankowski pisze w pozycji pt: Ogród przy dworze wiejskim z 1900 r., że potrzeba wprowadzenia roślin do wnętrz budynków wynika z długiego okresu jesieni i zimy w polskiej przyrodzie, kiedy to w parkach nie kwitną kwiaty. Na początku do wnętrz przenoszono rośliny krajowe, z czasem zaczęto sprowadzać gatunki obce. Za sprawą badań etnograficznych i przyrodniczych prowadzonych przez uczonych, przywożono do Europy nasiona, cebulki i korzenie nieznanych dotąd roślin. W 1733 r. w Europie zakwitł pierwszy storczyk z Wysp Bahama. W 1779 r. sir Josef Banks przywiózł z Nowej Zelandii pierwszą araukarię, a w 1819 r. z Brazylii przywieziono pierwszy gatunek amarylisa. Wynalezienie skrzynki Warda, w której gleba utrzymywała jednakową wilgotność, umożliwiło transport roślin egzotycznych.

Już „Grecy mieli upodobanie [w kwiatach] posągi Bogów nimi stroili; biesiadujący nosili je na głowie, a stoły w takim razie kwiatami posypywano. Przybijano nad wrotami uploty kwiatów ile razy w domu coś się pomyślnego zdarzyło.” Za czasów Rzymian „nie dość było wtedy na uplotach i wieńcach, wszystkie pokoje kwiatami natrząsano. Nie tylko pokoje, łóżka, ale i przysionki pałacu Cesarza usłane były kwiaty" [Wodzicki 1820]. 
Na wielu rycinach i dawnych fotografiach ukazujących wnętrza pałaców i dworów udokumentowano rośliny doniczkowe i wyposażenie wnętrz służące do ekspozycji roślin tj. donice, żardiniery i gerydony. Oprócz zastosowania we wnętrzach mieszkalnych rośliny doniczkowe wystawiano na otwartym powietrzu w parkach, wzdłuż alejek spacerowych, na podjeździe i na tarasach.

Wspomniany Edmund Jankowski jak mówi o sobie - „stary ogrodnik Ogrodu Pomologicznego w Warszawie, redaktor Ogrodnika Polskiego i inspektor Szkoły Ogrodniczej” jest również autorem poradnika o warunkach uprawy roślin pokojowych pt. Kwiaty naszych mieszkań z 1880 r. Notuje w nim, że człowiek pokusił się stworzyć sztuczne warunki potrzebne do wzrostu i rozwoju roślin, więc zgromadził pod jednym dachem - rośliny z południa, takie jak: palmy, kaktusy, storczyki oraz rośliny z północy: iglaste i paprocie. Do tego celu budowano szklarnie, gdzie przy pomocy szkła i ogrzewania zapewniano roślinom dostateczne ciepło i odpowiednie oświetlenie. Następnie rośliny przeniesiono do mieszkań, gdzie miały „umilić je zielonością, odświeżyć powietrze, orzeźwić myśli przypomnieniem lata wśród zimy". Często rośliny musiały egzystować w ciężkich warunkach „w pokojowym pyle, w dusznej często długo nieprzewietrzanej atmosferze, nieraz z dala od światła a zbyt blisko pieca".

Jankowski [1880] podaje, że ,pod biedną strzechą dworku [...] kwiaty muszą poprzestać tylko na skromnym kąciku,”. Zamożniejsi właściciele ustawiali rośliny w pokojach otwieranych tylko podczas przyjęć. Najbogatsi tworzyli za pomocą kwiatów okazałe i niezwykłe pokojowe ogrody, w których gromadzili rzadko spotykane „cuda natury i przepychy sztuki”. Autor zauważa, że rośliny potrzebują podobnych warunków jak ludzie. Co ciekawe, Jankowski pisze, że rośliny zabierają nocą tlen, potrzebny zarówno ludziom jak i roślinom do oddychania. Proponuje, żeby na rośliny przeznaczyć tylko jedno okno w pokoju, inne okna pozostawiając wolne, tak aby nie zacieniać mieszkania, lub ustawić na każdym oknie tylko kilka kwiatów. W widnych pokojach szczególnie interesująco wyglądały girlandy bluszczu rozpięte na drutach i ułożone w linie lub festony.

W angielskim poradniku Gardening indoors and under glass Rockwell [1912] podaje najczęściej uprawiane rośliny pokojowe. Były to: rośliny kwitnące, krzewy, ozdobne z liści, pnącza, paprocie, palmy, kaktusy oraz rośliny cebulowe. Ten sztuczny botanicznie podział wynika ze zbliżonych wymagań uprawy roślin. Do najczęściej uprawianych, z grupy roślin kwitnących należały, takie rośliny jak: begonia, fuksja, geranium, pelargonia, heliotrop, petunia, pierwiosnek, lwia paszcza i in. Do krzewów pokojowych autor zaliczył m.in.: abutilon, azalię, buwardię, hibiskus, hortensję, lantanę, cytrynę, oleander, pomarańczę, różę, słodką oliwkę. Z roślin ozdobnych z liści wymienił: alternanterę, araukarię, aspidistrę, kaladium, koleus, dracenę, pandan, pieprz, fikus, skalnicę, mimozę, tradescantię, marantę. Do grupy pnączy zaliczył: cissus, powojnik, kobeę pnącą, hoję, bluszcz, tojeść rozesłaną, powój, nasturcję, groszek pachnący, thunbergię. Większość paproci należy do jednej z trzech grup Nephrolepis, Adianthum lub Pteris, i są to m.in. nefrolepis wyniosły, orliczka, paprotnik sierpowaty, szparag pierzasty. Do najbardziej eleganckich roślin ozdobnych należały palmy: liwistona, karłatka wyniosła, palma kokosowa, kariota parząca. Jak pisze Rockwell [1912] żadne inne rośliny nie są tak odporne jak kaktusy. Mogły one być ustawione na wąskiej półce lub na krawędzi w oknie szklarni. Uprawiano kaktusy z rodzaju Mammillaria, Epiphyllum, Pilosocereus, Echinopsis oraz echinokaktus, opuncję i agawę. Do najbardziej satysfakcjonujących roślin domowych kwitnących zimą, zwłaszcza dla domów miejskich i apartamentów należały rośliny cebulkowe tj. tulipany, narcyzy, frezje, amarylis lub lilie. Równie chętnie uprawiano: iksję, sparaksis, szczawik, cantedeskię, cyklamen, amarylis, gloksynię, agapant baldaszkowy, begonię, mieczyk, konwalię, kosaciec, tawułkę japońska, jaskier i anemony.

Jankowski [1880] pisze, że dla lepszych warunków uprawy roślin, powietrze powinno być nawilżane przez rozłożenie pomiędzy doniczkami gąbki lub obłożenie doniczek wilgotnym mchem. Zamiast zastawiać kwiatami okna, stoły i inne sprzęty budowano latarnie (Ryc. 1,2) - pod nazwą rozumie się oszklone balkony, a może nią być tylko nisza na kwiaty albo rodzaj 
altany, w której rośliny zbierano pod ścianami, a pośrodku ustawiano krzesła i stolik. Latarnia bywała oddzielona od reszty salonu kotarką, którą można było zasłaniać na czas sprzątania lub zbyt mocnego ogrzewania pokoju lub zbyt silnego oświetlenia. Roślinom szkodziło ciepło pieca lub płomieni gazowych oraz sadze z lamp i świec, które osiadały na liściach.
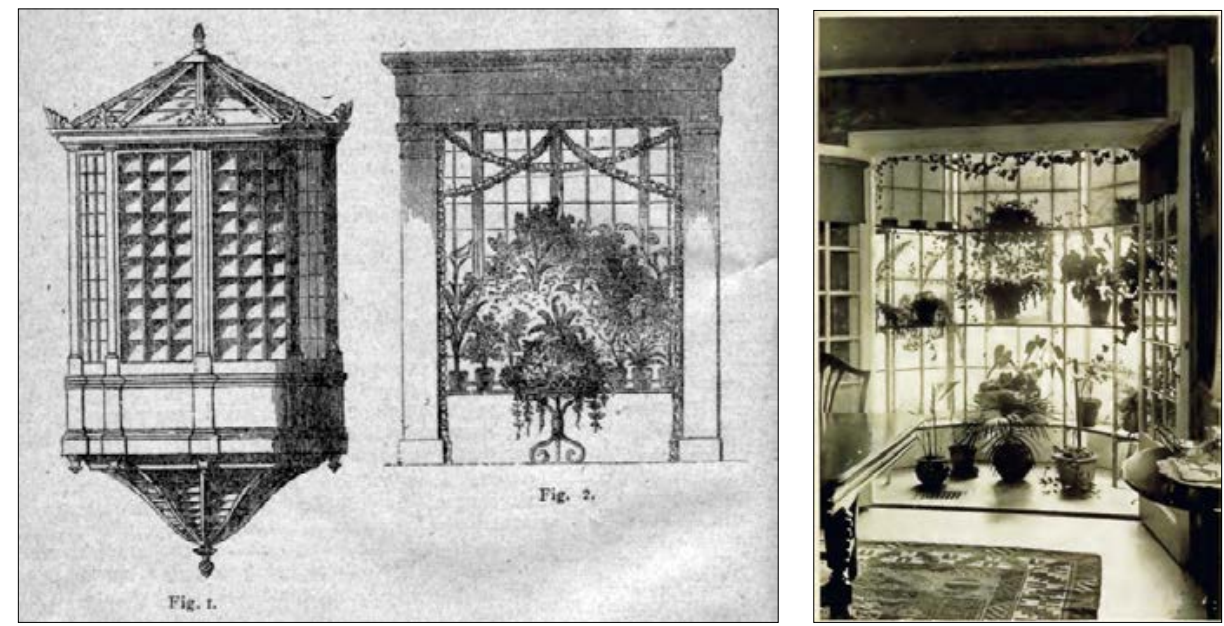

Ryc. 1. Oszklony balkon (Jankowski 1880)

Fig.1. Glazed balcony (Jankowski 1880)

Ryc. 2. Oszklony balkon, widok z wnętrza mieszkania (Rockwell 1912)

Fig. 2. Glazed balcony, the view from inside the apartment (Rockwell 1912)

Uprawa roślin w sezonie letnim odbywała się na przystawkach (galeryjkach) przy oknach. Kilka cali poniżej okna umieszczano deskę nachyloną ku ulicy, na żelaznych podpórkach. $\mathrm{Na}$ deskę sypano piasek rzeczny, który zapewniał wilgotność powietrza dla roślin. Od zbytniego żaru zabezpieczano daszkiem płóciennym (markizą). Wystawę można było uzupełnić o rośliny kobiercowe tworząc klombik. Wystawkę można było również obsadzić roślinami pnącymi z rodzajów Clematis, Caprifolium i Cobea.

Innym rodzajem kwietnika była wystawka wewnętrzna - rodzaj oszklonej szafy przystawionej do okna i zajmującej do $2 / 3$ jego powierzchni (Ryc. 3). W przypadku dużego mrozu była ona dogrzewana przez palenie w szafie lampy o matowym szkle, przy czym wywietrznik powinien być lekko uchylony [Jankowski 1880]. 


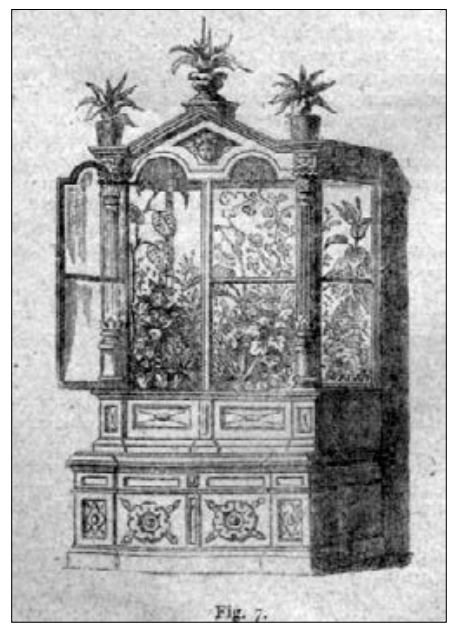

Ryc. 3. Wystawka wewnętrzna - rodzaj oszklonej szafyprzystawionej do okna (Jankowski 1880)

Fig. 3. Kind of glazed cabinets attached on the window (Jankowski 1880)

W pokojach z dużymi oknami urządzano osobne szklarnie dla roślin (z niem. Blumenschrank) (Ryc. 4,5). Na jednej ze ścianek mogło znajdować się lustro, które optycznie powiększało liczbę roślin. Taki kiosk był ozdobą salonu, jeśli był estetycznie wykończony oraz harmonizował ze stylem pozostałego umeblowania. We wnętrzu małej pokojowej szklarni mogły znajdować się skały, figury i fontanna. Niekiedy zamiast $\mathrm{w}$ doniczkach rośliny sadzono w szczelinach skał np. rośliny z rodzaju Bromeliaceae, storczyki, paprocie, ukośnice, maranty. Najokazalsze rośliny ustawiano po środku i przy ściankach szklarni [Jankowski 1880].
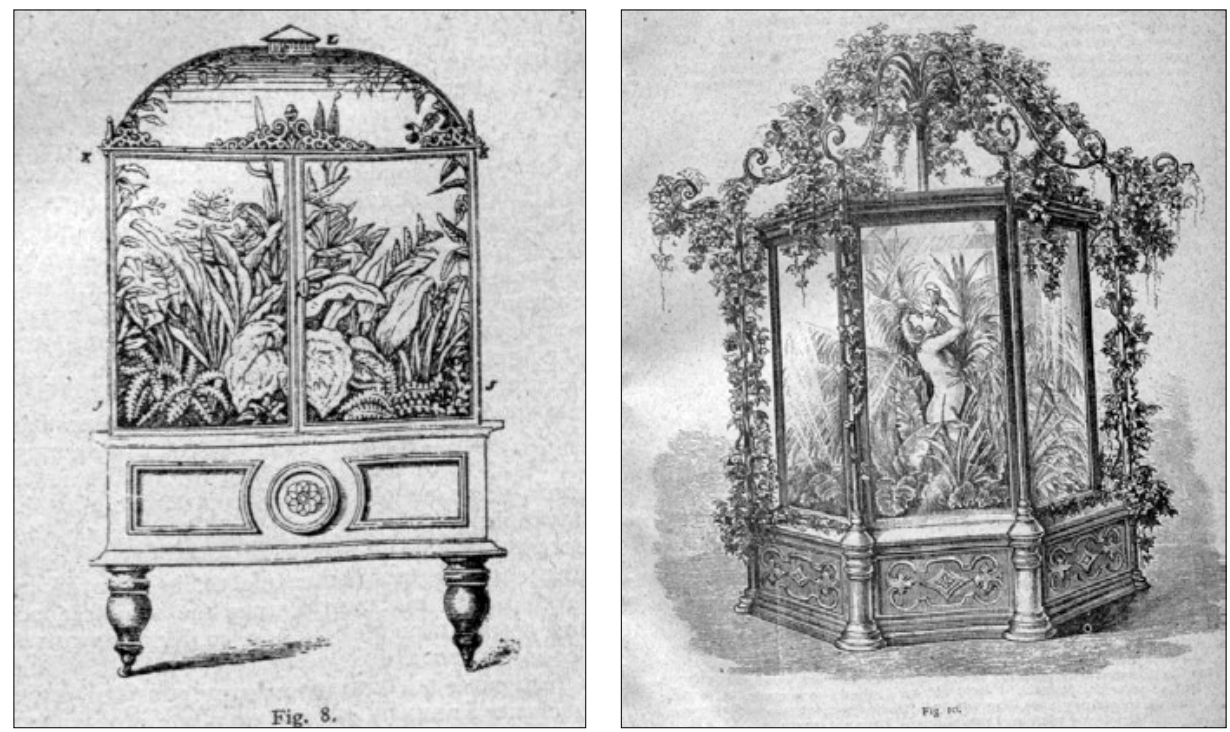

Ryc. 4, 5. Wolno stojące szklarnie dla roślin (Jankowski 1880)

Fig. 4, 5. Greenhouses for plant (Jankowski 1880)

Bluszczem oplatano framugi okien, do czego służyły dwie doniczki ustawione po obu stronach okien. Na widnych ścianach w gałązki bluszczu ujmowano ramy obrazów i luster, oraz rzeźbione popiersia. Interesująco wyglądały białe ściany salonu poprzedzielane na duże tafle 
splotami bluszczu, który również tworzył obwódki przy suficie i okrywał lamperie, ozdabiano również balkony $\mathrm{i}$ balustrady. Urządzano również pokojowe altany z bluszczu, usytuowane w pobliżu okna. Bluszczem zdobiono również obrus stołu ze święconką i domowe ołtarzyki. Używano dwóch odmian: leśny drobnolistny i irlandzki o liściach dużych i jaśniejszych. Ponadto uprawiano winobluszcz nowoholenderski, buławnicę pięcioklapową, rozwłócznię [Jankowski 1880].
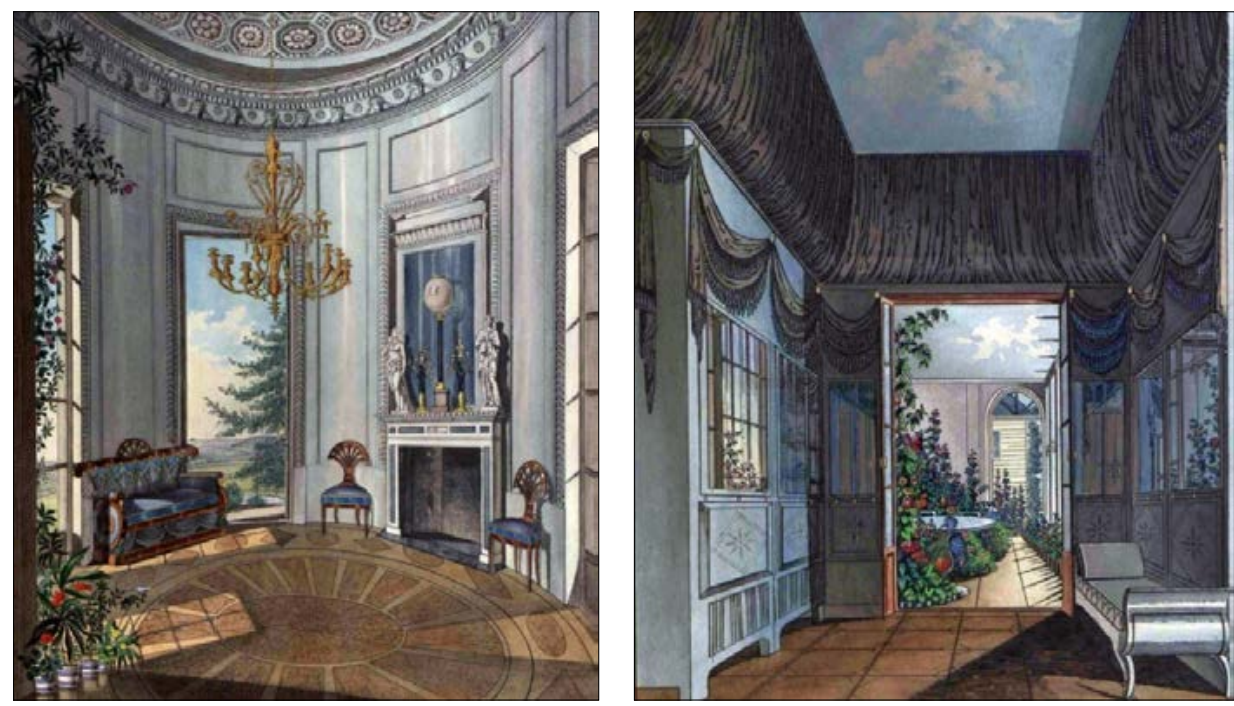

Ryc. 6. Salon Górny w pałacu M. Morskiej (Morska 1836)

Ryc. 7. Gabinet Popielaty w pałacu M. Morskiej (Morska 1836)

Fig. 6. Top Salon in the palace M. Morska (Morska 1836)

Fig. 7. Grey's Office in the palace M. Morska (Morska 1836)

W pokojach dobrze oświetlonych rośliny ustawiano w koszach kwiatowych (Ryc. 8, 9, 10). W koszach komponowano wiele gatunków roślin. Za podstawę służyła blaszana wanienka, na której płaszczyźnie ustawiano doniczki. Najczęściej spotykane były koszyki plecione. Jednak praktyczniejsze były kosze żelazne z drutu. W Niemczech takie kosze były tylko podstawą, którą zdobiono w medaliony wyszywane w różne wzory, obwieszano je frędzlami i festonami. Całość miała kształt stożka, gdzie w środku ustawiano wysoką roślinę np. dracenę, palmę itp. Brzegi koszów ozdabiano roślinami pnącymi (bluszcz, zielistka) lub rośliny wspinały się po podpórkach nad koszem [Jankowski 1880]. 

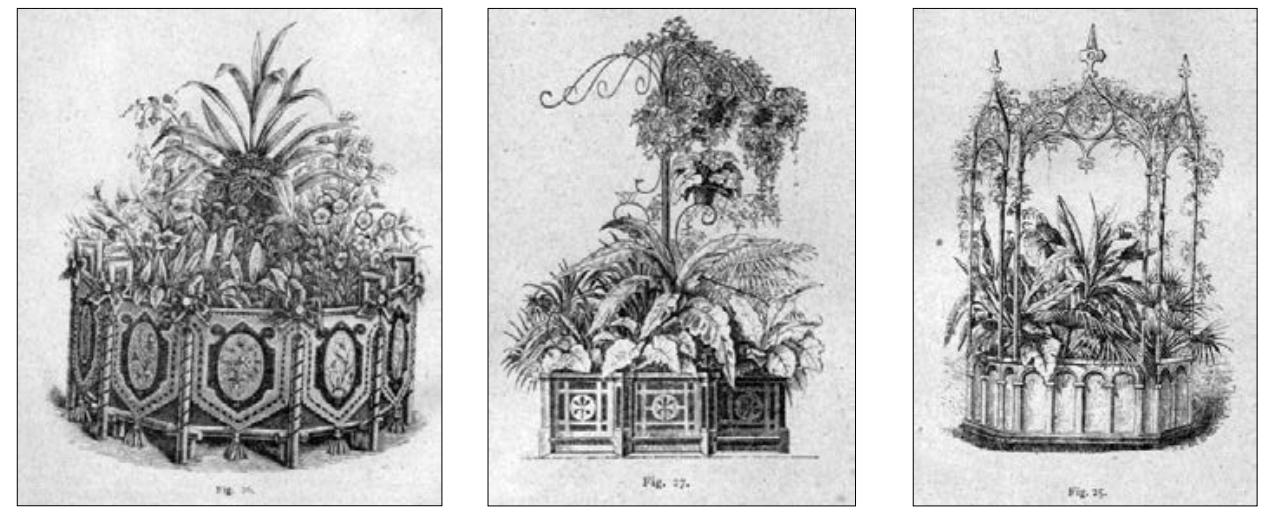

Ryc. 8, 9, 10. Różne Rodzaje koszy kwiatowych (Jankowski 1880)

Fig. 8, 9, 10. Different types of baskets of flowers (Jankowski 1880)

Rośliny o liściach zwisających np. paprocie uprawiano w tzw. ampułkach - naczyniach wiszących. Jednak nie był to często spotykany sposób uprawy, ponieważ sufity w pokojach w pałacach i dworach znajdowały się za wysoko, przez co trudno było pielęgnować i podlewać te rośliny. Kształt ampułek był zwężony u dołu, co powodowało problem z ustawieniem doniczki, oraz brak możliwości odpływu nadmiaru wody. Ampułki zawieszano przy oknach, za pomocą trzech sznurków lub mocniejszych łańcuszków. Najwygodniejsze były ampułki spuszczane na sznurku. Jako „rośliny ampułkowe” stosowano: trzykrotkę, zielistkę, grubosz, barwinek pospolity i pstrolistny, tojeść, wiciokrzew i bluszcz. Rośliny sadzono pojedynczo lub komponowano po kilka łącząc pstre z zielonymi lub szerokolistne z drobnolistnymi np. paproć umieszczona $\mathrm{w}$ środku, a z brzegów ułanka lub analogicznie zielistka i rozety rojnika [Janowski 1880].

Do uprawy delikatnych, pojedynczych roślin niewielkich rozmiarów np. storczyków stosowano szklane dzwony, nazywane również przyrządem Mintera (munter’s Apparat). Część dolna napełniona była ziemią liściową, a góra szczelnie zamknięta kloszem szklanym.

Następnym sposobem uprawy było terrarium, przeznaczone do urządzenia przez osoby o rozwiniętym zmyśle artystycznym, ponieważ w urządzeniu można było stworzyć miniaturowe obrazy. Podstawą urządzenia był przygotowany grunt, często formowany w skały, góry i groty. Terrarium mogło być odkryte lub przykryte szkłem. Terrarium służyło zwłaszcza miłośnikom kaktusów i roślin takich jak Crassula, Sedum, Echeveria itp. Jeśli terrarium naśladuje ląd, góry lub krajobraz nizin, to odwzorowaniem świata wody było akwarium. Przy czym akwarium oprócz uprawy roślin sprzyjało obserwacji zwierząt wodnych. Słupki akwariów były żelazne lub mosiężne, a podstawę ustawiano na solidnym stole dębowym. Kształt naczynia był zwykle sześcienny. Ozdobą akwarium były ładne kamienie i muszle. Wodę natleniano fontanną. Już w XIX w. istniało akwarium słonowodne w Berlinie, z płaszczkami i morskimi konikami, krabami i koralami [Janowski 1880].

W pozycji książkowej pod redakcją M. Todorowskiej [2005] stwierdzono, że u progu XIX w. nowością było ustawianie w salonach dużych naczyń z roślinami cebulowymi m.in. hiacynty, które zakwitały w lutym. Do ozdób wnętrz należała również żardiniera, czyli podstawa do kwiatów, głównie doniczkowych, zwykle w formie stolika, na której znajduje się wkład blaszany do ustawienia doniczek (ryc. 11).

Zbiór projektów Perciera i Fontaine`a, zawiera wiele różnorodnych modeli żardiniery, co potwierdza jej popularność w 1. poł. XIX w. (ryc. 12). Jeden z prostszych modeli to przenośny stolik, ale są również żardiniery bardziej skomplikowane, ustawione pośrodku pokoju, okrągłe lub wieloboczne, wsparte na nogach w kształcie kolumienek, dźwigających pojemnik 
wyłożony metalem. Ponad nimi wznosi się jeszcze jedna kondygnacja, zwieńczona dekoracyjnym motywem.

W meblarstwie istniały również okrągłe stoliki, zw. gerydon. Zachowała się pewna liczba gerydonów przedstawiających dzieci lub nimfy, np. gerydony znajdujące się w Wersalu i Ecole des Beaux-Arts oraz niewolników murzyńskich niosących tacę lub Maurów. Gerydon służył do ustawienia kwiatów w doniczce, wazonu z kwiatami, ale również świecznika, słodyczy lub do gier.

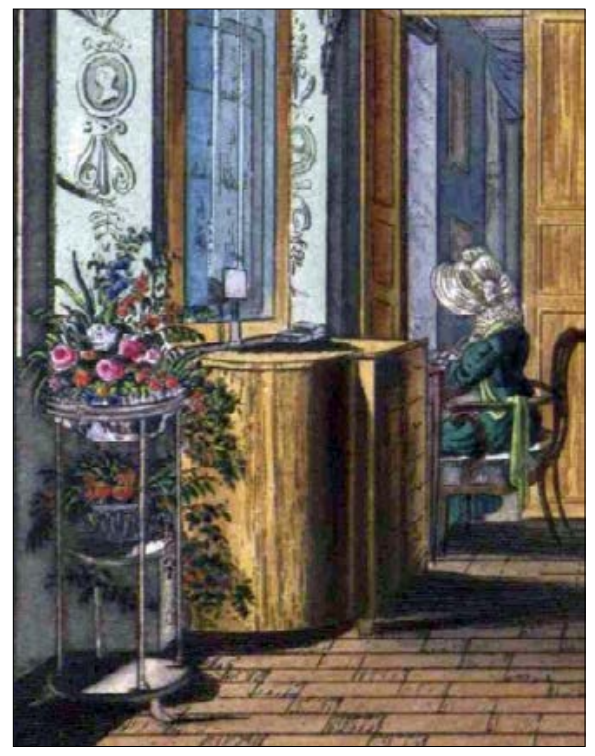

Ryc. 12. Ozdobny gerydon wykonany w Szwecji (Percier i Fontaine 1801)

Fig. 12. Ornate gerydon made in Sweden (Percier and Fontaine 1801

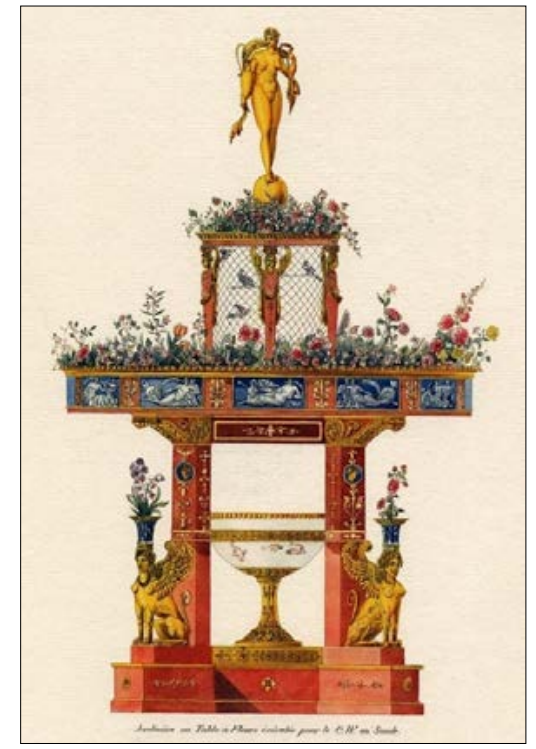

Ryc. 11. Żardiniera w Gabinecie Popielatym w pałacu M. Morskiej (Morska 1868)

Fig. 12. Jardinjere in the Cabinet of gray in the palace M. Morska (Morska 1868)

Dla roślin cebulkowych, palm, dracen i większości pozostałych używano doniczek tzw. hiacyntowych. Do paproci, ukośnic, aspidistry i sansewierii potrzebne są donice płaskie i szerokie. Najmniejsze donice nazywane były sadzonkowymi. A większe niż $5 \mathrm{~cm}$ średnicy oznaczano nazwami od roślin w nich uprawianych np. goździkowe, rezedowe, lakowe [Jankowski 1900].

Surowy wygląd doniczek (z wypalonej gliny, niepowlekane) pozostawał w kontraście z pozostałym umeblowaniem wnętrza dworu lub pałacu. Dlatego doniczki wstawiano w osłonki - tzw. ozdobne wazoniki lub też okrywano je „pochewkami” (ryc. 13, 14). Wazony były wykonywane z fajansu, porcelany, metalu, również w stylu mebli. Pochewki mogły być wykonane z papieru lub innej materii. Wyróżniano pochewki składane - klejone z czterech tekturek, które rozsuwano stosownie do wielkości doniczki. Do pędzenia hiacyntów w wodzie używano naczyń szklanych lub porcelanowych w postaci urn [Jankowski 1880].

Stosowano również ceramiczne osłonki doniczkowe ang. cache pot. Były to wykonane $\mathrm{z}$ fajansu osłonki do kwiatów, często dekorowane kobaltem w sceny rodzajowe [Teodorowska 2005]. 

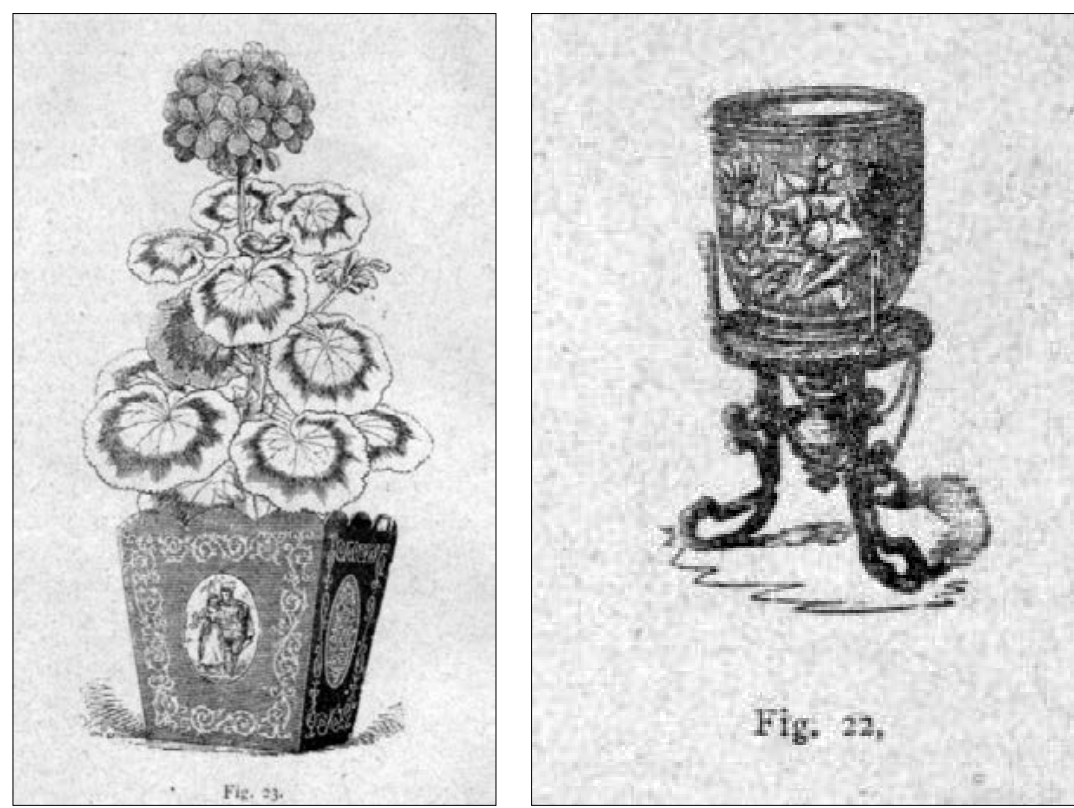

Ryc. 13, 14. Osłonki na doniczki używane w XIX w. - z papieru i metalowa (Jankowski 1880)

Fig. 13, 14 Caps on the pots used in the nineteenth century - from paper and metal (Jankowski 1880)

Kubły wykonywało się z klepek dębowych, pojemnik był wewnątrz wypalony, na dnie osmołowany i przedziurawiony, obity żelaznymi obręczami, z dwoma uchwytami do przenoszenia. Do uprawy cytryn i pomarańcz używano skrzyń złożonych ze ścianek oddzielnych, zbitych klinami [Jankowski 1880]. Wodzicki [1820] pisze o podziale pojemników do sadzenia roślin na doniczki (wykonywane bez szkliwionej powłoki, które szerokość powinny mieć dwa razy większą niż wysokość) i kubły. Kułby wykonywano z drewna dębowego, w kształcie okrągłym albo „graniaste na nóżkach stojące” czyli sześcienne, tzw. pojemniki wersalskie. Najlepszym rozwiązaniem była taka konstrukcja pojemnika, która umożliwiała otwieranie go na boki, w celu kontroli rozwoju korzeni lub w momencie przesadzania rośliny (Ryc. 15, 16). Pojemniki tego typu powinny być pomalowane, co przyczyni się do ozdoby ogrodu, oraz umacniane żelaznymi obręczami.

Kubłów drewnianych - dębowych lub sosnowych używano do dużych roślin. Kubły cylindryczne lepsze były od pojemnika o formie sześciennej. Zalecano, aby kubeł wzmocniony był przez ściśnięcie dwiema żelaznymi obręczami. Z zewnątrz kubły malowano farbą olejną, wewnątrz wypalano i zabezpieczano naftą [Jankowski 1900]. 


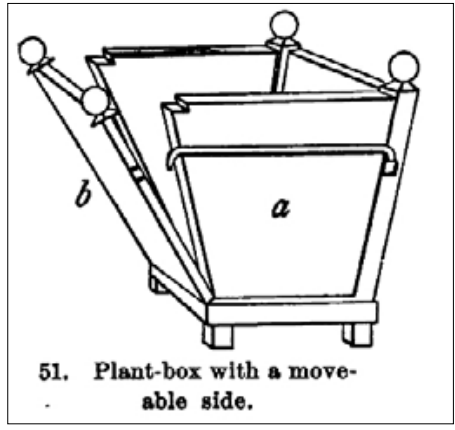

Ryc. 15. Aleja prowadząca do oranżerii, Wersal (Budziłowicz 1860)

Fig. 15. Avenue leading to the conservatory, Versailles (Budziłowicz 1860)

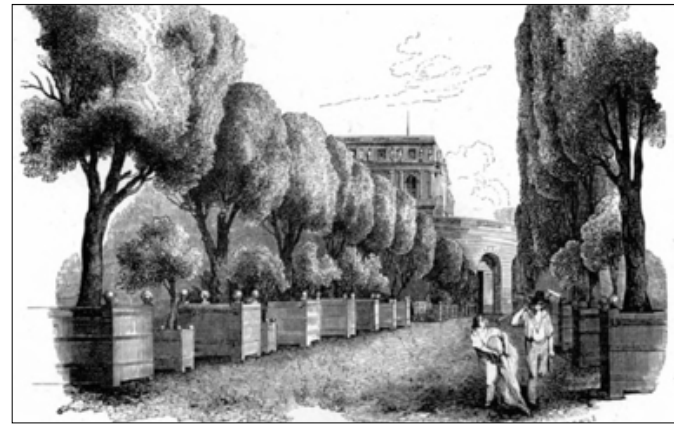

Ryc. 16. Pojemnik wersalski otwierany na boki (Bailey 1898)

Fig. 16. Versailles container opened to the side (Bailey 1898)

Rośliny o dużych liściach okrywających doniczkę lub pędach zwieszonych - ananasowate, storczyki, paprocie, ukośnice i pnące, ustawiano na kwietnikach. Rodzajem kwietników były schodki (franc. etagere), które umieszczano w narożnikach, pod ścianami lub oknami (Ryc. 17, 18). Nowoczesnym na tamte czasy rozwiązaniem były składane ramiona żelazne, które przyśrubowywano do framugi okna lub ściany. Na ramionach znajdowały się podstawki z podwyższonym brzegiem. Do ustawiania doniczek służyły też półgzymsy [Jankowski 1880].
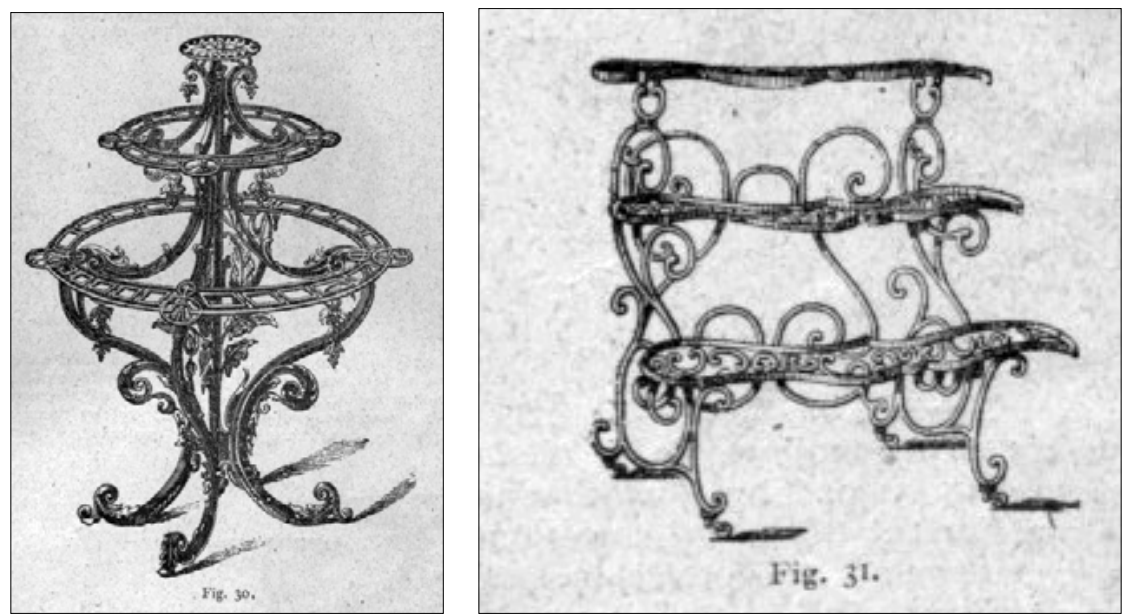

Ryc. 17, 18. Kwietniki stosowane w mieszkaniach w XIX w. (Jankowski 1880)

Fig. 17, 18. Table for flowers used in homes in the nineteenth century (Jankowski 1880)

Podczas lata rośliny doniczkowe wystawiano na tarasy. Przy czym zwracano uwagę na potrzeby świetlne roślin. Jako pierwsze, na początku maja wystawiano się cytryny i oleandry. W razie przymrozków przykrywano je matami słomianymi. Przez kilka pierwszych dni rośliny pozostawiano w cieniu budynku lub drzewa przyzwyczajając je do słońca. Jankowski [1880] podaje, że z nastaniem wiosny rośliny należy hartować i przenosić na zewnątrz, na przykład na ganek. Rośliny wystawiano w cieniu drzew tworząc ozdobne klomby o kształcie koła lub elipsy. W środku ustawiano rośliny najwyższe, ku brzegowi coraz niższe. Wysokie rośliny przywiązywano do palików. Pod doniczkami robiono zagłębienia narzędziem podobnym do ubijaka brukarskiego, tak aby korzenie nie sięgały do gleby, i aby do doniczek nie dostały się dżdżownice. Rośliny przenoszono do budynku pod koniec września [Jankowski 1880]. 
Rośliny wystawiane na werandę w: skrzyniach, doniczkach lub wiszących koszykach. Często stosowaną kompozycją podokienną w skrzyni była dracena, róża pomarszczona i barwinek. Kosze wykładano mchem torfowcem i sadzono szczawik, bluszcz, oraz geranium [Rocwkell 1912].

Ogrodniczka M. Morska w pozycji pt. Zbiór rysunków wyobrażajacy celniejsze budynki z 1836 r. podaje opis 10 bukietów na każdy miesiąc ułożony według czasu kwitnienia kwiatów (Rys. 19, 20). Np. bukiet nr I - z roślin kwitnących od 1 do 15 czerwca: piwonia, kalina, złotokap, kosaciec, irys, chaber bławatek, lilak pospolity, róża, kosaciec syberyjski, wiciokrzew, dyptam i miesięcznica; bukiet nr II - z roślin kwitnących i ozdobnych od 1 do 15 sierpnia: jarzębina, pysznogłówka, przetacznik, malwa, jeżówka, dalia, róża, bniec biały, dzielżan jesienny, krwawnica.
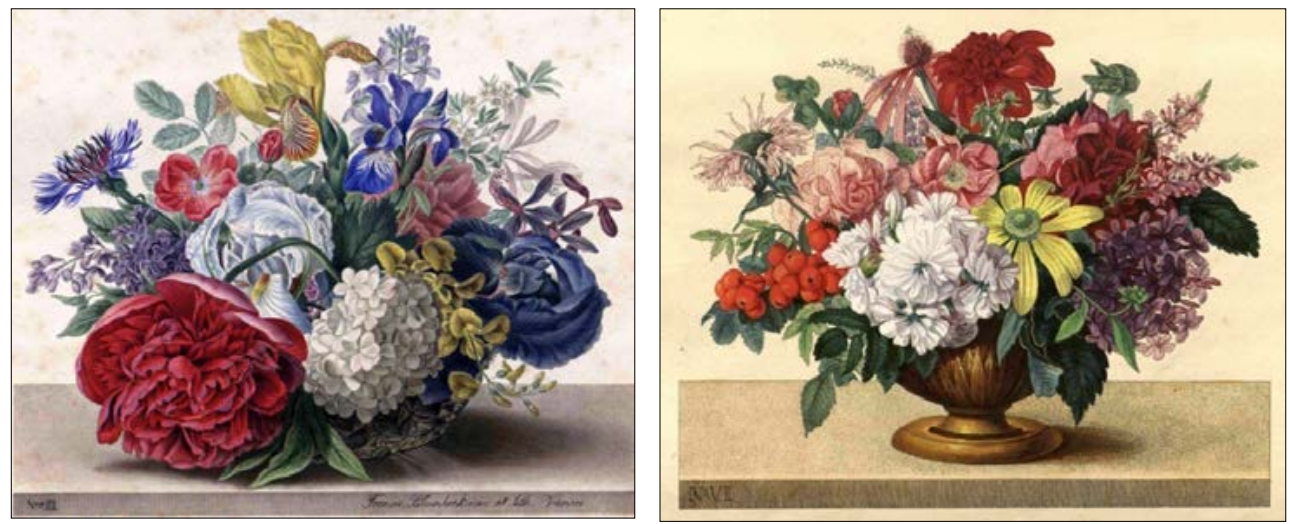

Ryc. 19, 20. Propozycje bukietów do wnętrz dworów - bukiet nr I - z roślin kwitnących od 1 do 15 czerwca - bukiet nr II - z roślin kwitnących od 1 do 15 sierpnia (Morska 1836) Fig. 19, 20. Proposals bouquets for indoor courts - a bouquet No. I - blooms from 1 to 15 June - a bouquet No. II - blooms from 1 to 15 August (Morska 1836)

O ciekawym sposobie uprawy rośliny Isolepis R.Br. (sitniczki) napisano w Ogrodniku Polskim z 1881 r. Niemcy do uprawy tej rośliny w pokoju używali szklanych naczyń rozszerzonych u dołu, w których umieszczali złote rybki. U góry w zwężoną szyjkę wstawiano doniczkę Isolepis gracilis, tak aby korzenie sięgały wody.

Gołębiowski [1830] pisze, że „róża zawsze była królową kwiatów w ogrodzie, ją w ogrodzie, ją w domach trzymać lubiono". W skromniejszych domach szlacheckich, latem - w niedzielę i święta (zwłaszcza Zielone Świątki i Boże Ciało) posypywano podłogę tatarakiem (dawniej tatarskie zioło, ajer). Na Litwie dodawano również listki kwiatów - róży, chabrów, piwonii, niekiedy posiekane gałązki jałowca.

Wnętrza XIX w. dworów i pałaców ozdabiano również niekiedy pojemnikami na potpurii - mieszanka wonnych suchych płatków kwiatowych z ziołami, przyprawami, owocami, lotnymi olejkami. Była to wczesna forma odświeżaczy powietrza. Pierwsze wazony na potpurrii powstały we Francji, skąd rozpowszechniły się na całą Europę. Wazony miały perforowane wieczka lub ścianki, do rozchodzenia się zapachu po wnętrzach mieszkania. Pojemniki te posiadały bogatą dekorację plastyczną z motywami przeważnie roślinnymi, i wykonane były z porcelany, szkła lub metalu. Miały formę pudełka, wazy lub misy. Formy wazonów ustawiano na kominkach, komodach, stolikach kawowych, a patery na stołach. 


\title{
PODSUMOWANIE
}

1. W procesie aranżacji wnętrza historycznego ważne jest, aby wykonać właściwy dobór gatunkowy do stylu mieszkania.

2. Do ekspozycji roślin stosowano specjalne meble pokojowe np. gerydon, żardiniera.

3. Rośliny komponowano w koszach kwiatowych, wolno stojących oranżeriach, przeszklonych balkonach, terrariach, wiszących koszach, doniczkach i drewnianych skrzyniach.

4. Osłonki do doniczek terakotowych wykonywano $\mathrm{z}$ fajansu, metalu i papieru oraz ozdabiano malowidłami lub płaskorzeźbami z motywami flory i scen rodzajowych.

\section{PIŚMIENNICTWO}

Ogrodnik Polski. 1881 R.3 nr 19

Bailey L. H., 1989. Garden making. London

Budziłowicz I., 1860. Versailles et Trianon; Versailles: palais et jardins - 5 édition. Paris.

Gołębiowski Ł., 1830. Domy i dwory. Warszawa.

Jankowski E., 1880. Kwiaty naszych mieszkań. Warszawa.

Jankowski E., 1900. Ogród przy dworze wiejskim. Warszawa.

Majdecka A., 2007.Rewaloryzacja parków w dydaktyce Studium Podyplomowego Ochrony i Konserwacji Zabytkowych Założeń Ogrodowych. [w:] Czasopismo Techniczne 10: 225-226.

Morska M., 1836. Zbiór rysunków wyobrażający celniejsze budynki. Wiedeń.

Percier Ch., Fontaine P. 1801. Recueil de décorations intérieures comprenant tout ce qui a rapport a l'ameublement, comme vases, trépieds, candelabres, cassolettes, lustres, girandoles, lampes, chandeliers, cheminées, feux, poêles, pendules, tables, secrétaires, lits, canapés, fauteuils, chaises, tabourets, miroirs, ecrans composés par C. Percier et P.F.L. Fontaine. Hessling.

Pudelska K., 2001. Park dworski na Felinie - historia i stan aktualny. [w:] Zeszyty Naukowe Akademii Rolniczej im. H. Kołłątaja w Krakowie 279: 161- 165.

Rockwell F.F., 1912. Gardening indoors and under glass. Nowy York.

Todorowska M. [red.], 2005. Popoludnie w ogrodzie - wystawa zabytkowych mebli ogrodowych. Wyd. Muzeum Sopotu.

Wodzicki S., 1820. O chodowaniu, użytku, mnożeniu i poznawaniu drzew, krzewów, roślin i ziót. Kraków.

\section{SELECTION OF SPECIES AND CROPS INDOORS POLISH PALACES AND MANSIONS IN THE NINETEENTH CENTURY}

\begin{abstract}
The flowers were planted in pots and bowls in the times of Homer. The illustrations can be seen early Egyptian plants in pots standing in the garden in symmetrical patterns. At the beginning of the interiors of residential mansions and palaces transferred domestic plants, over time began to bring alien species imported by botanists from all over the world. The article presented important species used as a plant room in the nineteenth century, and describes the furniture and containers for exposure of plants used in those days. The interior design of the historical process, it is important to take the proper selection of species to the style of the apartment.
\end{abstract}

Keywords: palace, mansion, potted plants 